ISSN 1678-3921

Journal homepage: www.embrapa.br/pab

For manuscript submission and journal contents, access: www.scielo.br/pab

\section{Pasture organic management using thermopotassium and thermophosphate in the Cerrado region}

\begin{abstract}
The objective of this work was to evaluate the performance of the thermopotassium and thermophosphate agrominerals, as sources of $\mathrm{P}$ and $\mathrm{K}$, in an organic pasture consortium of 'Marandu' Urochloa brizantha + Stylosanthes spp. in the Brazilian Cerrado. The organic management was compared with conventional farming using chemical fertilizers, during three years, in two adjacent experiments, one with and the other without previous growth of green manure (Crotalaria juncea). The management treatments were: conventional, with the application of $200 \mathrm{~kg} \mathrm{ha}^{-1}$ potassium chloride, $260 \mathrm{~kg} \mathrm{ha}^{-1}$ triple superphosphate, and $217 \mathrm{~kg} \mathrm{ha}^{-1}$ urea; organic, with the application of $1.0 \mathrm{Mg} \mathrm{ha}^{-1}$ thermophosphate, $2.0 \mathrm{Mg} \mathrm{ha}^{-1}$ termopotassium, and 7.0 Mg ha ${ }^{-1}$ chicken manure; and control, without fertilizers. Soil fertility, dry mass production, and legume content in the pasture were evaluated. The experiment with green manure resulted in a significant increase in the soilextractable contents of $\mathrm{P}$ and $\mathrm{K}$ and in pasture productivity. In the organic treatment, due to the slow release of agromineral nutrients, long-term effects are observed on the soil-extractable contents of $\mathrm{P}$ and $\mathrm{K}$.
\end{abstract}

Index terms: forage, grass, legume, organic fertilizer, potassium.

\section{Manejo orgânico de pastagens com uso de termopotássio e termofosfato na região do Cerrado}

Resumo - O objetivo deste trabalho foi avaliar o desempenho dos agrominerais termopotássio e termofosfato, como fontes de $\mathrm{P}$ e K, em consórcio de pastagem orgânica de Urochloa brizantha 'Marandu' + Stylosanthes spp. no Cerrado brasileiro. O manejo orgânico foi comparado ao convencional com uso de fertilizantes químicos, durante três anos, em dois experimentos adjacentes, um com e outro sem cultivo prévio de adubo verde (Crotalaria juncea). Os tratamentos de manejo foram: convencional, com aplicação de $200 \mathrm{~kg} \mathrm{ha}^{-1}$ de cloreto de potássio, $260 \mathrm{~kg} \mathrm{ha}^{-1}$ de superfosfato triplo e $217 \mathrm{~kg} \mathrm{ha}^{-1}$ de ureia; orgânico, com aplicação de $1,0 \mathrm{Mg} \mathrm{ha}^{-1}$ termopotássio, 2,0 $\mathrm{Mg} \mathrm{ha}^{-1}$ termofosfato e 7,0 Mg ha ${ }^{-1}$ cama de frango; e controle, sem adubação. Foram avaliadas fertilidade do solo, produção de matéria seca e contribuição da leguminosa na pastagem. $\mathrm{O}$ experimento com adubação verde proporcionou aumento significativo nos teores de $\mathrm{P}$ e $\mathrm{K}$ extraíveis do solo e na produtividade da pastagem. No tratamento orgânico, devido à liberação lenta dos nutrientes dos agrominerais, são observados efeitos de longo prazo nos teores extraíveis de $\mathrm{P}$ e $\mathrm{K}$ do solo.

Termos para indexação: forragem, gramínea, leguminosa, fertilizante orgânico, potássio. 


\section{Introduction}

Agrominerals are defined as natural inorganic materials that were processed only physically, presenting characteristics that improve agricultural soils and provide nutrients to plants (Luz et al., 2010). In addition, they are considered a soil conditioner, as their application improves soil physical, chemical, and biological characteristics (Ribeiro et al., 2010), by, for example, neutralizing soil acidity and reducing aluminum and sodium toxicity (Manning, 2010). Duarte (2013) evaluated the production of several crops and observed the efficacy of agrominerals containing phosphorus and potassium, pointing them as alternatives to conventional fertilizers, mainly in organic management systems.

In these systems, the use of alternative regional fertilizers, such as agrominerals, is strategic for pasture crops grown in low fertility soils as those of the Brazilian Cerrado region (Soares et al., 2014). Amending the acidity and fertility of these soils is paramount for pasture growth and for an increase in forage nutrition levels both in conventional and organic management systems.

However, the recommended sources of nutrients and acidity amendments differ for each management system. According to the norms for organic production, known as IN 46 (Brasil, 2011) in Brazil, limestone and gypsum (mineral of phosphogypsum) may be used for soil application, besides some agrominerals containing $\mathrm{P}$ and $\mathrm{K}$. Among the list of permitted agrominerals, thermophosphates, hyperphosphates, rock phosphates, and thermopotassium are cited. However, the use of soluble sources of sulfates, nitrates, phosphates (such as simple or triple superphosphate), as well as potassium chloride, are not allowed in organic production (Brasil, 2011).

The thermophosphates used in Brazil are produced by smelting of igneous phosphate rocks, such as apatite, with magnesium silicate $(\mathrm{MgSiO})$, at about $1,500^{\circ} \mathrm{C}$. This agromineral has, on average, $18 \%$ total $\mathrm{P}_{2} \mathrm{O}_{5}$, of which around $16.5 \%$ is soluble in citric acid (Soares et al., 2000). Although insoluble in water and, therefore, with an apparently low available P content, some studies have shown that, even short term, thermophosphates can be equally or more efficient than water-soluble fertilizers in providing this nutrient to plants (Melo et al., 2005).
Thermopotassium is produced from "verdete", a dark-green, silicate, sedimentary rock. This agromineral has a long residual effect, is alkaline, and is a source of many plant nutrients (Epstein, 2009). It is made of quartz, feldspar, and micas, and its chemical composition does not present $\mathrm{Cl}$ and has a low saline index (Silva et al., 2012). Furthermore, the P content in the rock matrix presents a very low solubility in water, which needs to be increased after the nutrient is applied to soils through a thermo-chemical treatment with the addition of calcium carbonate $\left(\mathrm{CaCO}_{3}\right)$ and/or calcium silicate $\left(\mathrm{CaSiO}_{3}\right)$.

Despite the different used nutrient sources, conventional and organic pasture management systems may benefit from the use of fodder legumes, as they can fix atmosphere nitrogen. These legumes are a lowcost source of $\mathrm{N}$, which also increases organic mass in soils, and decisively interfere in the quality and productivity of pastures. Their use improves the litter quality of pasture soils and may provide considerable amounts of $\mathrm{N}$ to soil-plant-animal systems (Lüscher et al., 2014).

Intercropping fodder legumes with pastures contributes to $\mathrm{N}$ uptake by grasses, increasing pasture support capacity (Azevedo Junior et al., 2012). Moreover, $\mathrm{N}$ fixed by fodder legumes may improve the dietary quality and growth of animals (Pirhofer-Walzl, 2012; Lüscher et al., 2014). During the dry season, when the nutritive value of pastures decreases, animals are better nourished in those intercropped with fodder legumes (Azevedo Junior et al., 2012).

The objective of this work was to evaluate the performance of the thermopotassium and thermophosphate agrominerals, as sources of $\mathrm{P}$ and $\mathrm{K}$, in an organic pasture consortium of 'Marandu' Urochloa brizantha + Stylosanthes spp. in the Brazilian Cerrado.

\section{Materials and Methods}

The experiment was conducted at Embrapa Cerrados, located in Planaltina, Distrito Federal, Brazil $\left(15^{\circ} 35^{\prime} 30^{\prime \prime} \mathrm{S}, 47^{\circ} 42^{\prime} 30^{\prime \prime} \mathrm{W}\right.$, at an average altitude of 1,007 m). The climate of the region is of the AW type according to Köppen, with an annual average precipitation of 1,460 mm (Figure 1).

The soil was classified as a Latossolo Vermelho distrófico (Santos et al., 2018), i.e., an Ustox Acrustox Oxisol (Soil Survey Staff, 2015), with a low fertility, a 
clay texture, and the following chemical characteristics at $0-20 \mathrm{~cm}$ depth: $\mathrm{pH} 5.8,0.04 \mathrm{cmol}_{\mathrm{c}} \mathrm{dm}^{-3} \mathrm{Al}, 1.54$ $\mathrm{cmol}_{\mathrm{c}} \mathrm{dm}^{-3} \mathrm{Ca}+\mathrm{Mg}, 3.61 \mathrm{mg} \mathrm{dm}^{-3} \mathrm{P}$, and $47 \mathrm{mg} \mathrm{dm}^{-3} \mathrm{~K}$.

Two independent experiments were designed: E1GM, with a previous green manure (GM) crop, which was incorporated to the soil prior to the implementation of the experiment; and E2-NoGM, without the green manure crop. The experiments were then installed identically. In each of them, three treatments were set in a three randomized complete block designs, with three replicates per block. Treatments (conventional management, organic management, and control without fertilizers) were assigned to $10 \times 12 \mathrm{~m}$ plots, and cutting dates to subplots.

Two adjacent areas of 2,160 $\mathrm{m}^{2}$ each were selected for the experiments. In both areas, $2.0 \mathrm{Mg} \mathrm{ha}^{-1}$ limestone and $1.0 \mathrm{Mg} \mathrm{ha}^{-1}$ gypsum were applied. Then, after three months, $30 \mathrm{~kg} \mathrm{ha}^{-1}$ inoculated seeds of Crotalaria juncea L. (100 g inoculant for each $10 \mathrm{~kg}$ seeds) were sown. After 84 days of growth, $705 \mathrm{~kg} \mathrm{ha}^{-1}$ dry weight of crotalaria were incorporated into the soil. Crotalaria shoot analysis showed the following results: $24 \mathrm{~g} \mathrm{~kg}^{-1}$ $\mathrm{N}, 1.48 \mathrm{~g} \mathrm{~kg}^{-1} \mathrm{P}, 15.5 \mathrm{~g} \mathrm{~kg}^{-1} \mathrm{~K}, 8.1 \mathrm{mg} \mathrm{kg}^{-1} \mathrm{Ca}$, and 2.3 $\mathrm{mg} \mathrm{kg}^{-1} \mathrm{Mg}$, equivalent to $16.92,1.04,10.93,5.71$, and $1.62 \mathrm{~kg} \mathrm{ha}^{-1} \mathrm{~N}, \mathrm{P}, \mathrm{K}, \mathrm{Ca}$, and $\mathrm{Mg}$, respectively.

After crotalaria was incorporated into E1-GM, fertilizers were applied to each one of the areas, in the first two treatments. In the organic treatment:

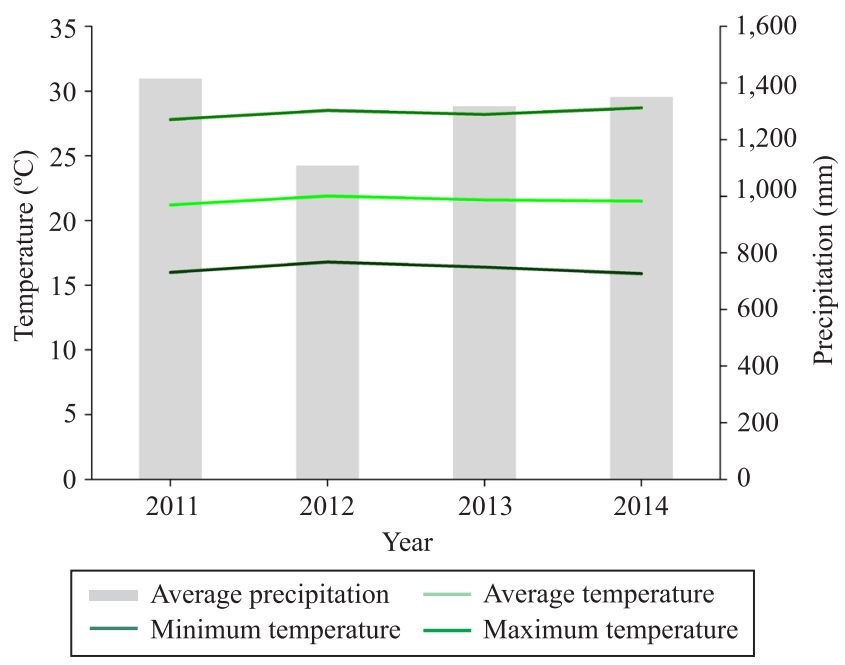

Figure 1. Air temperature and annual precipitation during the experimental period in Planaltina, Distrito Federal, Brazil.
7.0 $\mathrm{Mg} \mathrm{ha}^{-1}$ chicken manure $\left(15 \mathrm{~g} \mathrm{~kg}^{-1} \mathrm{~N}\right), 20 \mathrm{Mg} \mathrm{ha}^{-1}$ thermopotassium $\left(60 \mathrm{~g} \mathrm{~kg}^{-1} \mathrm{~K}_{2} \mathrm{O}\right)$, and 1.0. $\mathrm{Mg} \mathrm{ha}^{-1}$ thermophosphate $\left(120 \mathrm{~g} \mathrm{~kg}^{-1} \mathrm{P}_{2} \mathrm{O}_{5}\right)$ as sources of $\mathrm{N}, \mathrm{K}$, and $\mathrm{P}$, respectively. In the conventional treatment: 200 $\mathrm{kg} \mathrm{ha}^{-1}$ potassium chloride $\left(600 \mathrm{~g} \mathrm{~kg}^{-1} \mathrm{~K}_{2} \mathrm{O}\right), 260 \mathrm{~kg}$ $\mathrm{ha}^{-1}$ triple superphosphate $\left(460 \mathrm{~g} \mathrm{~kg}^{-1} \mathrm{P}_{2} \mathrm{O}_{5}\right)$, and $217 \mathrm{~kg}$ $\mathrm{ha}^{-1}$ urea $\left(460 \mathrm{~g} \mathrm{~kg}^{-1} \mathrm{~N}\right)$. The total supply of nutrients applied to each treatment (conventional or organic) was equivalent to $100 \mathrm{~kg} \mathrm{ha}^{-1} \mathrm{~N}, 120 \mathrm{~kg} \mathrm{ha}^{-1} \mathrm{P}_{2} \mathrm{O}_{5}$, and 120 $\mathrm{kg} \mathrm{ha}^{-1} \mathrm{~K}_{2} \mathrm{O}$. The control did not receive any fertilizer, except lime and gypsum.

The used thermopotassium was derived from verdete - containing from 6 to $14 \% \mathrm{~K}_{2} \mathrm{O}$ (Duarte et al., 2013) -, a silicate rock found in the municipality of Cedro de Abaeté, in the state of Minas Gerais, Brazil, composed mainly of glauconite, potassic feldspate, and micas (biotite and muscovite) (Luz et al., 2010). For the production of thermopotassium, a mixture containing $67 \%$ verdete and $33 \%$ calcium carbonate was calcinated at $1,100^{\circ} \mathrm{C}$ (Luz et al., 2010). Thermopotassium presents potassic minerals, such as kalsilite and leucite, as well as calcium silicates, which show high water solubility (Silva et al., 2018). The used thermopotassium had a granular form and the following chemical composition: $60 \mathrm{~g} \mathrm{~kg}^{-1} \mathrm{~K}_{2} \mathrm{O}, 110.1$ $\mathrm{g} \mathrm{kg}^{-1} \mathrm{Si}, 311 \mathrm{~g} \mathrm{~kg}^{-1} \mathrm{CaO}$, and $69 \mathrm{~g} \mathrm{~kg}^{-1} \mathrm{MgO}$.

After fertilized, both experiments were sown with mixed seeds of fodder legumes and grass. For this, $3.0 \mathrm{~kg} \mathrm{ha}^{-1}$ Stylosanthes spp. and $2.5 \mathrm{~kg} \mathrm{ha}^{-1}$ 'Marandu' Urochloa brizantha (A.Rich.) R.D.Webster were used. The sown fodder legumes were: 'Mineirão' Stylosanthes guianensis (Aubl.) Sw. (20\%), 'Campo Grande' Stylosanthes capitata Vogel with Stylosanthes macrocephala M.B.Ferreira \& Sousa Costa (20\%), and 'Bela' S. guianensis (60\%). During the experimental period, climatic conditions did not present large variations throughout the years (Figure 1).

The experiment was evaluated every six months, during three consecutive years (2011-2014), by cutting plant shoots. The cuttings were done at $10 \mathrm{~cm}$ from the ground level, within a square of $1.0 \mathrm{~m}^{2}$ thrown randomly in three different points of each plot. After that, the whole plot was mown evenly at $10 \mathrm{~cm}$ from the ground, and the produced biomass was removed from the area. The cuts were performed on: $7 / 25 / 2011$, 2/17/2012, 8/2/2012, 3/26/2013, 7/16/2013, and $1 / 15 / 2014$. The collected shoot samples were separated by grass or legume, and weighed in the field. The 
percentage in fresh weight of grass and legume plants was then calculated. Samples were oven-dried, at $65^{\circ} \mathrm{C}$, for 72 hours. The dried samples were weighed, milled, and analyzed chemically.

Once a year, composite soil samples were collected at $0-20 \mathrm{~cm}$ depth in each plot and were analyzed chemically (Donagema et al., 2011).

Statistical analyses were performed taking in account both experiments (E1-GM and E2-NoGM). The response variables were: dry mass productivity of intercropped pasture (U. brizantha and Stylosanthes spp.); and percentage of fodder legume in plots and chemical characterization of the soil, including values of $\mathrm{pH}$, soil organic matter, $\mathrm{P}, \mathrm{K}, \mathrm{Mg}, \mathrm{Ca}, \mathrm{Al}$, potential acidity $(\mathrm{H}+\mathrm{Al})$, cation exchange capacity $(\mathrm{CEC})$, and base saturation.

The analysis of variance and mean comparison by Tukey's test, at 5\% probability, were performed using the SAS software, version 9.4 (SAS Institute Inc., Cary, NC, USA).

\section{Results and Discussion}

The analysis of soil chemical attributes showed significant differences only for extractable $\mathrm{P}$ and $\mathrm{K}$, in both experiments (Table 1). The mean and standard deviation of the other soil chemical parameters were, respectively: 5.43 and 0.43 for $\mathrm{pH}, 32.5$ and $4.0 \mathrm{~g} \mathrm{~kg}^{-1}$ for organic matter, 1.00 and $0.34 \mathrm{cmol}_{\mathrm{c}} \mathrm{dm}^{-3}$ for $\mathrm{Mg}, 1.66$ and $0.53 \mathrm{cmol}_{\mathrm{c}} \mathrm{dm}^{-3}$ for $\mathrm{Ca}, 0.07$ and $0.04 \mathrm{cmol}_{\mathrm{c}} \mathrm{dm}^{-3}$ for $\mathrm{Al}, 5.27$ and $1.41 \mathrm{cmol}_{\mathrm{c}} \mathrm{dm}^{-3}$ for potential acidity, 8.10 and $1.49 \mathrm{cmol}_{\mathrm{c}} \mathrm{dm}^{-3}$ for CEC, and 35.19 and $9.19 \%$ for base saturation.

The average value of extractable $\mathrm{P}$ was $58 \%$ higher in E1-GM than in E2-NoGM, being 275\% higher in the control treatment, but decreasing over the years (Table 1). The use of green manure increased extractable K values, which were 71,67 , and $47 \%$ higher in the conventional, organic, and control treatments, respectively, in E1-GM. Extractable K did not differ in the control between experiments, but was higher in the conventional treatment in both experiments and in all years, except in the first one in E2-NoGM.

Over the years, the mean values of soil-extractable $\mathrm{P}$ were the highest in the first year in the control in E1-GM (Table 1), decreasing in the second and third years. Soil extractable P was lower in E2-NoGM, except in the second and third years in the organic treatment that showed the greatest $\mathrm{P}$ extractability in both experiments.

Soil extractable K was higher in the conventional treatment in E1-GM (Table 1), decreasing over the years. There was also a decrease in soil extractable $\mathrm{K}$ in the organic and control treatments throughout the three experimental years.

Table 1. Chemical attributes, in a three year period, of an Ustox Acrustox Oxisol, in experiments with (E1-GM) or without (E2-NoGM) the incorporation of green manure (GM), under the conventional management, organic management, and control (without fertilizers) treatments, in Planaltina, Distrito Federal, Brazil ${ }^{(1)}$.

\begin{tabular}{|c|c|c|c|c|}
\hline Green manure & Treatment & $1^{\text {st }}$ year & $2^{\text {nd }}$ year & $3^{\text {rd }}$ year \\
\hline & & & $\mathrm{P}\left(\mathrm{mg} \mathrm{dm}^{-3}\right)$ & \\
\hline \multirow{3}{*}{ E1-GM } & Conventional & $3.33(3.59) \mathrm{aA}$ & $1.90(1.2) \mathrm{aA}$ & $1.63(1.03) \mathrm{aA}$ \\
\hline & Organic & $0.48(0.36) \mathrm{bB}$ & $2.65(1.28) \mathrm{aA}$ & $2.28(1.10) \mathrm{aA}$ \\
\hline & Control & $2.11(1.12) \mathrm{aA}$ & $0.64(0.40) \mathrm{bB}$ & $0.55(0.35) \mathrm{bB}$ \\
\hline \multirow{3}{*}{ E2-NoGM } & Conventional & $0.55(0.43) \mathrm{aA}$ & $0.88(0.61) \mathrm{aA}$ & $0.75(0.53) \mathrm{aA}$ \\
\hline & Organic & $0.68(0.44) \mathrm{bA}$ & $2.25(1.72) \mathrm{aA}$ & $1.93(1.48) \mathrm{aA}$ \\
\hline & Control & $0.23(0.16) \mathrm{aA}$ & $0.35(0.37) \mathrm{aA}$ & $0.30(0.31) \mathrm{aA}$ \\
\hline \multirow{4}{*}{ E1-GM } & & & $\mathrm{K}\left(\mathrm{mg} \mathrm{dm}^{-3}\right)$ & \\
\hline & Conventional & $106.44(100.91) \mathrm{aA}$ & $82.33(24.00)$ abA & 70.81 (20.64) bA \\
\hline & Organic & $74.83(54.66) \mathrm{aB}$ & 70.50 (28.53) abB & $60.63(24.54) \mathrm{bB}$ \\
\hline & Control & $72.5(36.75) \mathrm{aB}$ & $52.33(8.98) \mathrm{abB}$ & 45.01 (7.72) bB \\
\hline \multirow{3}{*}{ E2-NoGM } & Conventional & $50.00(10.48) \mathrm{bA}$ & $52.75(11.36) \mathrm{aA}$ & 45.37 (9.77) bA \\
\hline & Organic & $35.60(6.92) \mathrm{bB}$ & $47.17(9.93) \mathrm{aB}$ & $40.56(8.54) \mathrm{bB}$ \\
\hline & Control & $30.80(3.55) \mathrm{bB}$ & $45.50(6.93) \mathrm{aB}$ & $39.13(5.96) \mathrm{bB}$ \\
\hline
\end{tabular}

${ }^{(1)}$ Means followed by equal letters, lowercase in the lines and uppercase in the columns within experiments, do not differ by Tukey's test, at $5 \%$ probability. Values between parentheses represent standard deviation $(n=4)$. 
The joint analysis of dry mass production from both experiments showed significant differences (Figure 2 $\mathrm{A}$ and $\mathrm{B})$. The cumulative dry mass production over the years in the conventional treatment was statistically similar to that in the organic treatment and higher than that in the control in both experiments (Figure $3 \mathrm{~A}$ and B).

The percentage of legumes in the organic and control treatments, in both experiments, was, in general, higher than in the conventional treatment, except in the fourth and in the last harvest date in E1-GM (Figure $4 \mathrm{~A}$ and $\mathrm{B}$ ).

InE1-GM, biomass incorporation may have promoted the release of organic compounds in the soil (Sharma et al., 2017). These compounds probably interacted with soil particles and decreased $\mathrm{P}$ adsorption in the soil (Rodrigues et al., 2021). The organic compounds from biomass degradation may have helped to increase $\mathrm{K}$ retention in soil colloids, increasing soil biological activity (Høgh-Jensen et al., 2006). These effects were detected until the last year both in the conventional and organic treatments. Improvements in soil quality, mainly chemical ones, after biomass incorporation, have been reported in other studies (Ramos et al., 2013). When considering the initial levels of soil extractable $P$ in E2-NoGM, a decrease was observed after one year of pasture growth. In this case, P may have been strongly adsorbed by soil particles (Rodrigues et al., 2021), since, during soil preparation for planting, the soil was moved intensively, receiving lime and being softened for plants to grow, operations that increased organic matter degradation.
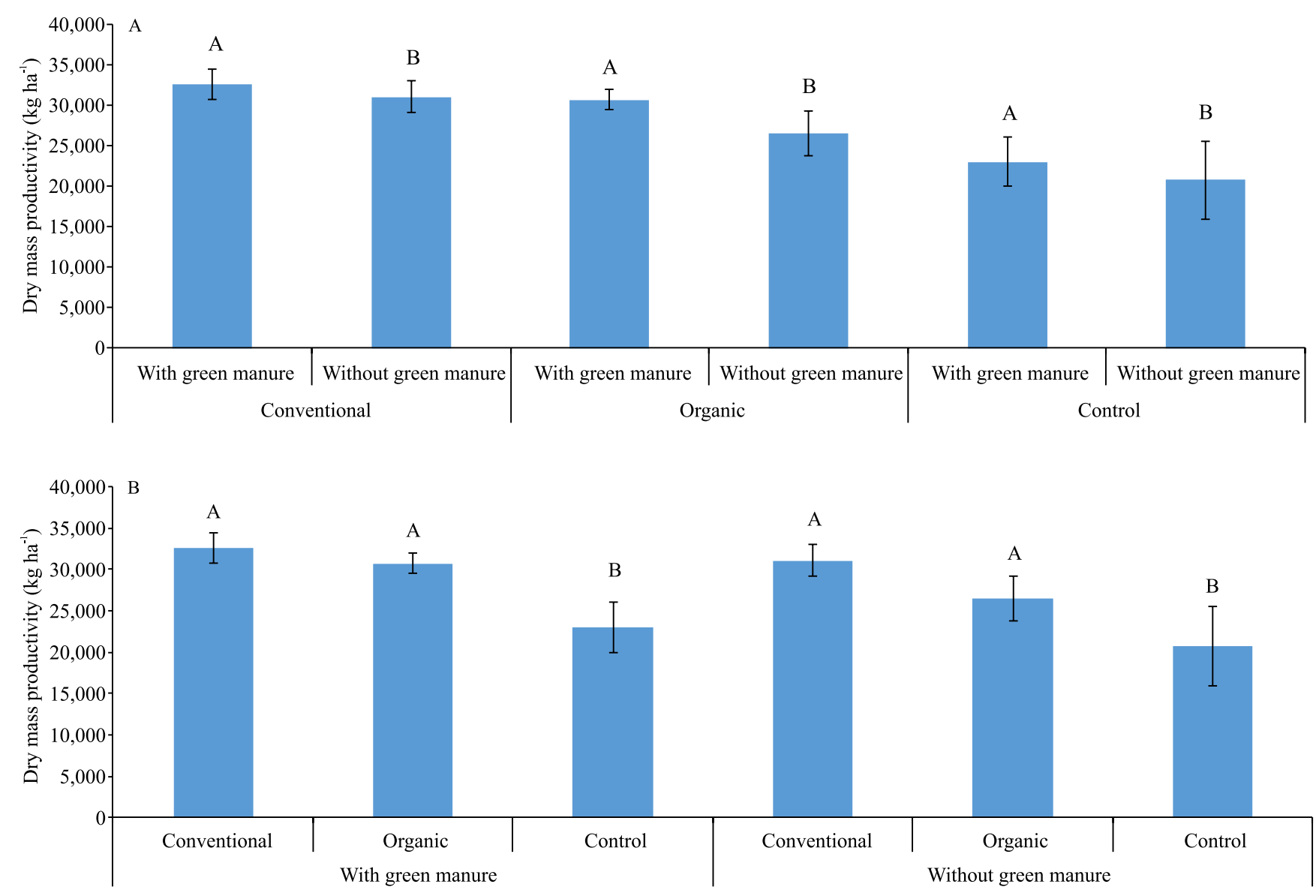

Figure 2. Dry mass productivity of 'Marandu' Urochloa brizantha and Stylosanthes spp., intercropped with or without the incorporation of green manure, under the conventional management, organic management, and control (without fertilizers) treatments, in Planaltina, Distrito Federal, Brazil. Equal letters within treatments (A) or experiments (B) do not differ by Tukey's test, at $5 \%$ probability. Vertical error bars refer to standard deviation. 
Alcântara et al. (2000), when evaluating, among other green manures, C. juncea as a fertilization strategy for Urochloa decumbens (Stapf) R.D.Webster pastures, observed an increase in the contents of extractable $\mathrm{Ca}, \mathrm{Mg}, \mathrm{K}$, as well as in CEC, in the soil. Furthermore, Rodrigues et al. (2021) reported that, after the incorporation of green manures, labile $\mathrm{P}$ increased from 5 to $20 \%$. Høgh-Jensen et al. (2006), however, concluded that, after a longer period, from 1 to 3 years, green manures increased $\mathrm{K}$ availability when deep-root species were grown, with plants extracting up to $95 \mathrm{~kg} \mathrm{ha}^{-1} \mathrm{~K}$ annually.

Soil extractable $\mathrm{P}$ in the organic treatment was similar to that in the conventional one in both experiments, except in the first year in E1-GM. Probably, as suggested
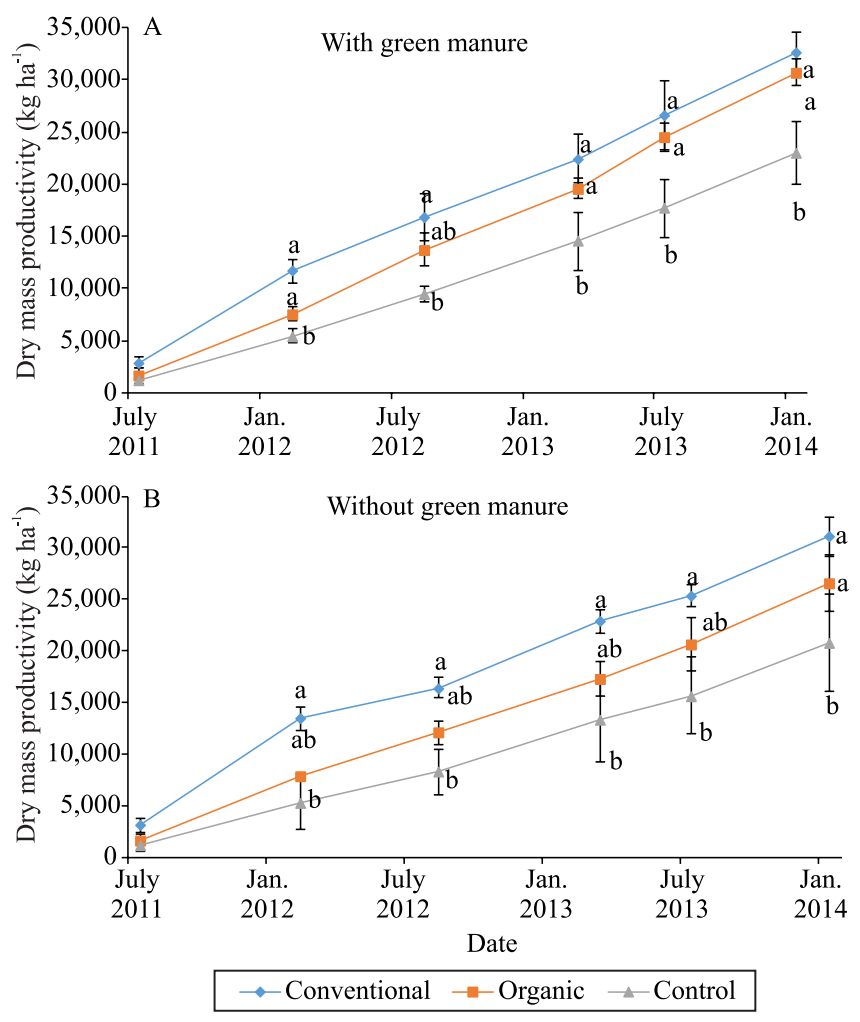

Figure 3. Accumulated dry mass productivity of 'Marandu' Urochloa brizantha and Stylosanthes spp., intercropped with (A) or without (B) the incorporation of green manure, under the conventional management, organic management, and control (without fertilizers) treatments, in Planaltina, Distrito Federal, Brazil. Equal letters within years do not differ by Tukey's test, at 5\% probability. Vertical error bars refer to standard deviation. by Stockdale et al. (2002), there was an increase in soil biological activity and water retention, among other chemical benefits of using an organic management, which impacted on P availability. However, the levels of extractable $\mathrm{P}$ were still considered low for plant growth $\left(<10 \mathrm{mg} \mathrm{dm}^{-3}\right)$ according to Sousa \& Lobato (2004), despite the fertilizer managements used in the experiments. The low availability of $\mathrm{P}$ is important as it may show differences among treatments, particularly for Urochloa sp., which is responsive to P fertilization and very efficient in absorbing $\mathrm{P}$ from soils with low levels of this nutrient (Soares et al., 2000).

The extraction of $\mathrm{K}$ from soil samples was highest in the conventional treatment during all evaluated years; however, a decrease was observed throughout the years. Duarte et al. (2013) found that K from sources such as $\mathrm{KCl}$ may leach as a function of high rates and of its high solubility, whereas Raij (2011) highlighted that the nutrient is prominent in soils with a low CEC. In the organic treatment, in which thermopotassium was applied, extractable $\mathrm{K}$ values were constant. This may be explained by the fact that thermopotassium solubility is low (Silva et al., 2012) and may release $\mathrm{K}$ slowly for a long time, reducing the chances of the occurrence of leaching (Ribeiro et al., 2010). In all treatments, the values of extractable $\mathrm{K}$ were considered within the average $\left(>40 \mathrm{mg} \mathrm{dm}^{-3}\right)$ for pastures (Sousa \& Lobato, 2004). In this case, the extractable $\mathrm{K}$ from the organic treatment was similar to that of the control; however, Orioli Júnior \& Coutinho (2009) found that, in pastures of 'Marandu' $U$. brizantha grown in poor fertility soils, mainly with low levels of $\mathrm{K}$, fertilization with thermopotassium increased significantly the availability of the nutrient to the plants.

In the first year in E2-NoGM, the extractable $\mathrm{P}$ and $\mathrm{K}$ levels for both the conventional and organic treatments were the lowest of all years. As this experiment received no green manure, it seems that it took a longer time for the pasture to establish and to increase biological activity, in order for the plants to start nutrient cycling. According to Stockdale et al. (2002), cycling processes of $\mathrm{P}$ and $\mathrm{K}$ are the same, but their rates may differ, especially when low solubility agrominerals are used.

Dry mass productivity differed between E1-GM and E2-NoGM (Figure $2 \mathrm{~A}$ and B). The accumulated values of pasture dry mass increased linearly for 
all treatments (Figure $3 \mathrm{~A}$ and $\mathrm{B}$ ). However, the conventional treatment produced the highest amount of dry mass in both experiments (Figure $3 \mathrm{~A}$ and B), with a greater difference specifically in the initial growth year when soluble fertilizers are rapidly dissolved and absorbed by plants (Duarte et al., 2013).

In E2-NoGM, the slow release of the applied fertilizers, i.e., chicken manure, thermophosphate, and thermopotassium in the organic treatment, only allowed a dry mass production similar to that of the conventional treatment in the last year (Figure $3 \mathrm{~A}$ ). In E1-GM, when green manure was incorporated, the pasture under the organic treatment increased its dry mass productivity, surpassing that of the conventional treatment after the fourth cut (Figure 3
B), probably due to the increased availability of $\mathrm{P}$ in the second and third years (Table 1). These results suggest that, in soils where the organic treatment with thermophosphate is applied, $\mathrm{P}$ availability may be higher in the long term.

In general, legume percentage in relation to $U$. brizantha was higher in E2-NoGM (19.6\%) than in E1-GM (9.3\%), being higher in the organic and control treatments in both experiments (Figure $4 \mathrm{~A}$ and B). By cut, the percentages obtained for the organic, conventional, and control treatments were 17, 20, and 7.0. The higher percentage of fodder legumes in the pasture shows their overall capacity to grow and compete in soils with a lower availability of nutrients (Soares et al., 2018).
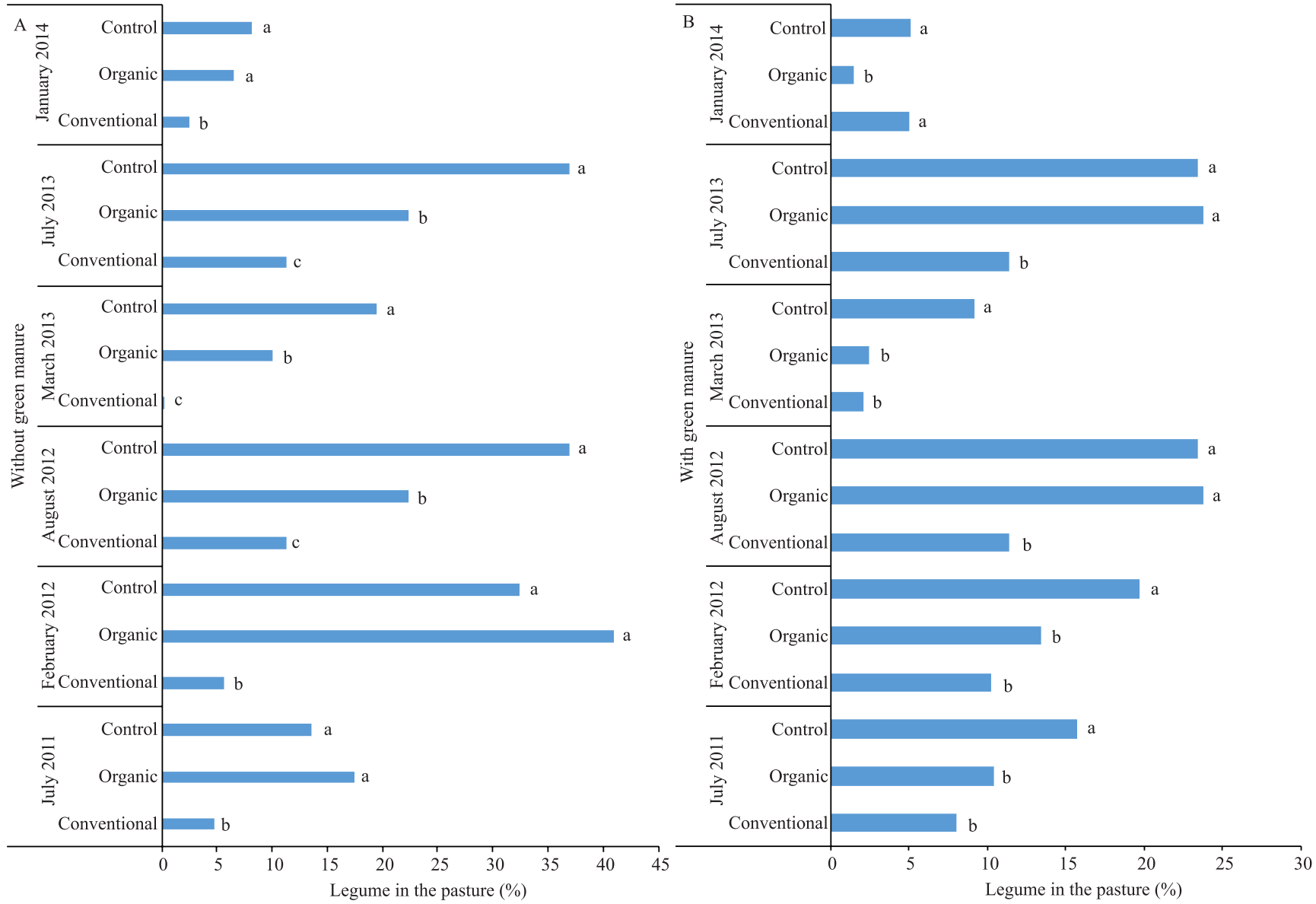

Figure 4. Stylosanthes spp. percentage in relation to 'Marandu' Urochloa brizantha, in an intercrop without (A) or with (B) the incorporation of green manure, under the conventional management, organic management, and control (without fertilizers) treatments, in Planaltina, Distrito Federal, Brazil. Equal letters within each date do not differ by Tukey's test, at $5 \%$ probability. 


\section{Conclusions}

1. Thermophosphate and thermopotassium fertilizers promote long-term effects on soil phosphorous and potassium extractability and on the growth of the 'Marandu' Urochloa brizantha + Stylosanthes spp. pasture consortium.

2. The incorporation of Crotalaria juncea green manure before pasture implementation increases productivity, mainly in the organic treatment, throughout the experimental years.

3. The organic pasture treatment increases the proportion of fodder legumes in the pastures, compared with the conventional and control treatments.

\section{Acknowledgments}

To Conselho Nacional de Desenvolvimento Científico e Tecnológico (CNPq), for support (edital Repensa-2010); and to projects Rede AgriRocha and Rede AgroBiocom, for financial support (Fundos Setoriais-Finep, 2009-2012).

\section{References}

ALCÂNTARA, F.A. de; FURTINI NETO, A.E.; PAULA, M.B. de; MESQUITA, H.A. de; MUNIZ, J.A. Adubação verde na recuperação da fertilidade de um Latossolo Vermelho-Escuro degradado. Pesquisa Agropecuária Brasileira, v.35, p.277-288, 2000. DOI: https://doi.org/10.1590/S0100-204X2000000200006.

AZEVEDO JUNIOR, R.L. de; OLIVO, C.J.; BEM, C.M. de; AGUIRRE, P.F.; QUATRIN, M.P.; SANTOS, M.M. dos; BRATZ, V.F.; HORST, T. Forage mass and the nutritive value of pastures mixed with forage peanut and read clover. Revista Brasileira de Zootecnia, v.41, p.827-834, 2012. DOI: https://doi.org/10.1590/S1516-35982012000400002.

BRASIL. Ministério da Agricultura, Pecuária e Abastecimento. Instrução Normativa ${ }^{\circ} 46$, de 6 de outubro de 2011. [Estabelece o Regulamento Técnico para os Sistemas Orgânicos de Produção Animal e Vegetal bem como as listas de Substâncias Permitidas para uso nos Sistemas Orgânicos de Produção Animal e Vegetal, na forma desta Instrução Normativa e dos seus Anexos I a VII]. Diário Oficial da União, 7 out. 2011. Seção1, p.4-11. Available at: $\quad<$ https://pesquisa.in.gov.br/imprensa/jsp/visualiza/index.jsp $? \mathrm{data}=07 / 10 / 2011 \&$ jornal $=1 \&$ pagina $=4 \&$ total Arquivos $=248>$. Accessed on: Apr. 152021.

DONAGEMA, G.K.; CAMPOS, D.V.B. de; CALDERANO, S.B.; TEIXEIRA, W.G.; VIANA, J.H.M. (Org.). Manual de métodos de análise de solo. 2.ed. rev. Rio de Janeiro: Embrapa Solos, 2011. 230p. (Embrapa Solos. Documentos, 132).

DUARTE, I.N.; PEREIRA, H.S.; KORNDÖRFER, G.H. Lixiviação de potássio proveniente do termopotássio.
Pesquisa Agropecuária Tropical, v.43, p.195-200, 2013. DOI: https://doi.org/10.1590/s1983-40632013000200003.

EPSTEIN, E. Silicon: its manifold roles in plants. Annals of Applied Biology, v.155, p.155-160, 2009. DOI: https://doi.org/10.1111/j.1744-7348.2009.00343.x.

HØGH-JENSEN, H.; NIELSEN, B.; THAMSBORG, S.M. Productivity and quality, competition and facilitation of chicory in ryegrass/legume-based pastures under various nitrogen supply levels. European Journal of Agronomy, v.24, p.247-256, 2006. DOI: https://doi.org/10.1016/j.eja.2005.10.007.

LÜSCHER, A.; MUELLER-HARVEY, I.; SOUSSANA, J.F.; REES, R.M.; PEYRAUD, J.L. Potential of legumebased grassland-livestock systems in Europe: a review. Grass and Forage Science, v.69, p.206-228, 2014. DOI: https://doi.org/10.1111/gfs.12124.

LUZ, A.B. da; LAPIDO-LOUREIRO, F.E.; SAMPAIO, J.A.; CASTILHOS, Z.C.; FERNANDES, M.S.B. Rochas, minerais e rotas tecnológicas para a produção de fertilizantes alternativos. In: FERNANDES, F.R.C.; LUZ, A.B. da; CASTILHOS, Z.C. (Ed.). Agrominerais para o Brasil. Rio de Janeiro: Cetem, 2010. p.61-88.

MANNING, D.A.C. Mineral sources of potassium for plant nutrition. A review. Agronomy for Sustainable Development, v.30, p.281-294, 2010. DOI: https://doi.org/10.1051/agro/2009023.

MELO, B. de; MARCUZZO, K.V.; TEODORO, R.E.F.; CARVALHO, H. de P. Fontes e doses de fósforo no desenvolvimento e produção do cafeeiro, em um solo originalmente sob vegetação de cerrado de Patrocínio - MG. Ciência e Agrotecnologia, v.29, p.315-321, 2005. DOI: https://doi.org/10.1590/S141370542005000200007.

ORIOLI JÚNIOR, V.; COUTINHO, E.L.M. Effectiveness of fused magnesium potassium phosphate for Marandu grass. Revista Brasileira de Ciência do Solo, v.33, p.1855-1862, 2009. DOI: https://doi.org/10.1590/S0100-06832009000600034.

PIRHOFER-WALZL, K.; RASMUSSEN, J.; HØGH-JENSEN, H.; ERIKSEN, J.; SØEGAARD, K.; RASMUSSEN, J. Nitrogen transfer from forage legumes to nine neighbouring plants in a multi-species grassland. Plant and Soil, v.350, p.71-84, 2012. DOI: https://doi.org/10.1007/s11104-011-0882-z.

RAIJ, B. van. Fertilidade do solo e manejo dos nutrientes. Piracicaba: International Plant Nutrition Institute, 2011. 420p.

RAMOS, B.Z.; TOLEDO, J.P.V.F.; LIMA, J.M. de; SERAFIM, M.E.; BASTOS, A.R.R.; GUIMARÃES, P.T.G.; COSCIONE, A.R. Doses de gesso em cafeeiro: influência nos teores de cálcio, magnésio, potássio e $\mathrm{pH}$ na solução de um Latossolo Vermelho distrófico. Revista Brasileira de Ciência do Solo, v.37, p.1018-1026, 2013. DOI: https://doi.org/10.1590/S010006832013000400019 .

RIBEIRO, L. da S.; SANTOS, A.R. dos; SOUZA, L.F. da S.; SOUZA, J.S. Rochas silicáticas portadoras de potássio como fontes do nutriente para as plantas solo. Revista Brasileira de Ciência do Solo, v.34, p.891-897, 2010. DOI: https://doi.org/10.1590/S0100-06832010000300030. 
RODRIGUES, M.; WITHERS, P.J.A.; SOLTANGHEISI, A.; VARGAS, V.; HOLZSCHUH, M.; PAVINATO, P.S. Tillage systems and cover crops affecting soil phosphorus bioavailability in Brazilian Cerrado Oxisols. Soil and Tillage Research, v.205, art.104770, 2021. DOI: https://doi.org/10.1016/j.still.2020.104770.

SANTOS, H.G. dos; JACOMINE, P.K.T.; ANJOS, L.H.C. dos; OLIVEIRA, V.Á. de; LUMBRERAS, J.F.; COELHO, M.R.; ALMEIDA, J.A. de; ARAÚJO FILHO, J.C. de; OLIVEIRA, J.B. de; CUNHA, T.J.F. Sistema brasileiro de classificação de solos. 5.ed. rev. e ampl. Brasília: Embrapa, 2018. E-book.

SHARMA, P.; LAOR, Y.; RAVIV, M.; MEDINA, S.; SAADI, I.; KRASNOVSKY, A.; VAGER, M.; LEVY, G.J.; BAR-TAL, A.; BORISOVER, M. Green manure as part of organic management cycle: effects on changes in organic matter characteristics across the soil profile. Geoderma, v.305, p.197-207, 2017. DOI: https://doi.org/10.1016/j.geoderma.2017.06.003.

SILVA, A.A.S.; MEDEIROS, M.E.; SAMPAIO, J.A.; GARRIDO, F.M.S. Verdete de Cedro do Abaeté como fonte de potássio: caracterização, tratamento térmico e reação com CaO. Revista Matéria, v.17, p.1062-1073, 2012. DOI: https://doi.org/10.1590/S1517-70762012000300004.

SILVA, R.R.; CARVALHO, I. de S.B.; ROCHA, S.D.F. Transformações químicas e mineralógicas em misturas de rocha potássica e calcário submetida a processo térmico visando a liberação do potássio contido. Tecnologia em Metalurgia, Materiais e Mineração, v.15, p.369-376, 2018. DOI: https://doi.org/10.4322/2176-1523.20181473.
SOARES, J.P.G.; LEAL, M.A. de A.; SALMAN, A.K.; ZAMORA LÓPEZ, G.F. Manejo da fertilidade de solos em áreas de pastagem orgânica. In: CARDOSO, I.M.; FÁVERO, C. (Ed.). Solos e agroecologia. Brasília: Embrapa, 2018. v.4, 373p. (Coleção Transição Agroecológica, 4).

SOARES, J.P.G.; NEVES, D.L.; CARVALHO, J.M. de. Produção de carne bovina em sistema orgânico: desafios e tecnologias para um mercado em expansão. In: OLIVEIRA, R.L.; BARBOSA, M.A.A. de F. (Org.). Bovinocultura de corte: desafios e tecnologias. 2.ed. atual. e ampl. Salvador: Edufba, 2014. v.1, p.701-725.

SOARES, W.S.; LOBATO, E.; SOUSA, D.M.G. de; REIN, T.A. Avaliação do fosfato natural de Gafsa para recuperação de pastagem degradada em Latossolo Vermelho-Escuro. Pesquisa Agropecuária Brasileira, v.35, p.819-825, 2000. DOI: https://doi.org/10.1590/S0100-204X2000000400020.

SOIL SURVEY STAFF. Illustrated guide to soil taxonomy. Version 2.0. Lincoln: Usda, 2015.

SOUSA, D.M.G. de; LOBATO, E. (Ed.). Cerrado: correção do solo e adubação. 2.ed. Brasília: Embrapa Informações Tecnológicas, 2004. 415p.

STOCKDALE, E.A.; SHEPHERD, M.A.; FORTUNE, S.; CUTTLE, S.P. Soil fertility in organic farming systems: fundamentally different? Soil Use and Management, v.18, p.301-308, 2002. DOI: https://doi.org/10.1111/j.1475-2743.2002. tb00272.x. 